\title{
A CEO VIEW OF THE KEY ISSUES IN AUSTRALIAN INFORMATION SYSTEMS MANAGEMENT -
} 1997

\author{
Graham Pervan \\ School of Information Systems \\ Curtin University of Technology \\ GPO Box U1987, Perth, Australia 6845 \\ Email: pervang@cbs.curtin.edu.au
}

\begin{abstract}
As part of a research programme on key information systems management issues, a survey of Australasia's largest 500 organisations was conducted to identify which issues were perceived by their chief executive officers (CEOs) as being important, problematic and critical over the next three to five years. The results reported are based on a relatively low response rate (though perhaps reasonable for the target group) so should be regarded as only exploratory. The most critical issues were revealed to be a mix of technology management issues (IT infrastructure, disaster recovery), strategic management issues (BPR, competitive advantage, information architecture), people management issues (organisational leaming), systems development and data management issues (effective use of the data resource, effectiveness/productivity of IS, effectiveness of software development), and their own support systems (EIS/DSS). This reflects their interest in a wide range of issues, but all with an organisation-wide focus. Non-critical issues were mostly related to the individual technologies and the place and role of IS in the organisation. While the CEOs showed some agreement with their chief information officers (CIOs) on issues such as the IT infrastructure, competitive advantage, and organisational learning some distinct differences exist, particularly in relation to the quality and effectiveness of systems and processes and also how CEOs and CIOs perceive each other.
\end{abstract}

\section{Keywords}

IS Management Issues; Data Resource Management; Organising IS; IS Research Issues.

\section{INTRODUCTION}

In recent years, and for the foreseeable future, organisations are facing rapidly changing business environments which challenge their executives (both IS and non-IS) to handle issues such as downsizing, outsourcing, leveraged buyouts, strategic alliances, flexible manufacturing, just-in-time scheduling, globalisation, business process reengineering and total quality management. These environmental changes place demands on their IS departments to support product innovation, new production techniques, and changing organisational designs, and provide timely, high-quality information.

Identifying and handling key issues in the management of information systems is essential for IS executives to support their organisations efficiently and effectively. The investigation of these key issues by researchers serves to enhance understanding of the concerns of IS executives and suggest relevant areas of investigation by IS management researchers. This particular study, which focuses on the views of CEOs on the key IS management issues, is part of a research program which aims to:

- determine the IS management issues most important, problematic and critical to Australasian executives (CIOs and CEOs) over the next 3-5 years;

- examine differences between the views of CIOs and CEOs to better understand their problems in relation to IS/TT;

- examine trends in the status of different issues over time;

- inform industry (IS and non-IS) of current and future issues;

- inform IS researchers of relevant issues to investigate.

\section{OTHER KEY IS MANAGEMENT ISSUES STUDIES}

Many key issues studies have now been carried out, but most (for example, Pervan 1996, Brancheau et al. 1996) have been concerned with the views of IS executives only. An historical summary of the few major studies which have included (and specifically presented) non-IS executive views is been provided in Table 1 below:

The most common research approach used has been the postal survey, either single-round or in three-round Delphi studies. All of the above studies have obtained opinions from IS managers and other non-IS managers. In most cases the organisations sampled have been quite varied in size and industry, and the sample sizes, number and type of issues have varied significantly. The studies have generally sought opinions of the major 'key' or 'critical' information systems management issues facing these organisations. This particular study has followed the methodology of the recent Australian CIO study (Pervan 1996) in considering issues as important (they have a significant impact within the organisation), problematic (they are difficult to manage), and critical (they are both important and problematic). 


\begin{tabular}{|l|c|l|l|c|l|}
\hline Authors & $\begin{array}{l}\text { Year of } \\
\text { Study }\end{array}$ & Country & $\begin{array}{l}\text { Sample } \\
\text { (Response rate) }\end{array}$ & $\begin{array}{l}\text { Total No. } \\
\text { of Issues }\end{array}$ & Research Method \\
\hline Brancheau \& Wetherbe & 1987 & U.S.A & $\begin{array}{l}\text { IS \& Gen. Mgrs. } \\
(68 / 180)\end{array}$ & 26 & $\begin{array}{l}\text { Three round Delphi } \\
\text { Survey }\end{array}$ \\
\hline Moynihan & 1990 & Ireland & $\begin{array}{l}\text { CEOs/TT Mgrs. } \\
(49 / ? ?)\end{array}$ & $? ?$ & Structured Interviews \\
\hline $\begin{array}{l}\text { Caudle, Gorr \& } \\
\text { Newcomer }\end{array}$ & 1991 & U.S.A & $\begin{array}{l}\text { PS Mgrs. } \\
(354 / 1054)\end{array}$ & 37 & Survey \\
\hline $\begin{array}{l}\text { Galliers, Merali \& } \\
\text { Spearing }\end{array}$ & 1992 & $\begin{array}{l}\text { United } \\
\text { Kingdom }\end{array}$ & $\begin{array}{l}\text { Managers (incl. } \\
\text { IS) (98/??) }\end{array}$ & 26 & Survey \\
\hline $\begin{array}{l}\text { Wang \& Turban } \\
\text { IS \& Gen. Mgrs. }\end{array}$ & Taiwan & $\begin{array}{l}\text { IS \& } \\
(297 / 928)\end{array}$ & Survey \\
\hline $\begin{array}{l}\text { Davis, Menon, Munday, } \\
\text { Thomson \& Young }\end{array}$ & 1995 & New Zealand & $\begin{array}{l}\text { Various } \\
(118 / 392)\end{array}$ & 23 & $\begin{array}{l}\text { Three round Delphi } \\
\text { Survey }\end{array}$ \\
\hline
\end{tabular}

Table 1: A History of Key Issues Studies involving Non-IS Executives

\section{THE KEY ISSUES}

As indicated in Table 1 (column 5), there are many different IS management issues. While most researchers accept that IS executives must handle many technology management (TM) issues, there is a growing acceptance that there are many strategic management (SM) issues which are equally, if not more, important. Other categories of issues include systems development and data management (SDDM), people management (PM), and end-user computing (EUC). The issues in each category are listed in Table 2 below. (For a thorough description and explanation of each issue, see Pervan (1997).) These issues have changed over time, but those included below are identical to the most recent Australian study of CIOs (Pervan 1996, 1997).

\section{RESEARCH DESIGN}

In order to provide information concerning the key IS management issues, a postal survey of the CEOs of the top 500 Australasian organisations was conducted in February/March, 1997. The mailing list used was identical to that used for the CIO study in 1996. In the course of the development of this mailing list, some organisations were removed because they were either subsidiary to other (larger) organisations on the list or because we were aware they had a company policy against participation in any surveys. A final list of 452 CEOs was produced. Each questionnaire was identified by printing the organisation's rank on each page so that the responses were not anonymous (but confidential of course). This enabled key financial indicators for each responding organisation to be extracted from the original source of the Top 500 list (Jaques 1995).

The aim of this study was to identify the key IS management issues for these organisations over the next 3-5 years. The approach taken was similar to the most recent Australian CIO study (Pervan 1996) where the respondents were asked to rate both how important and how problematic each issue was for their organisation. A list of 31 issues with an associated paragraph of explanation for each issue was produced (the same list as for the CIO study). In addition to the brief title for each issue, a paragraph explaining the issue (its 'rationale') was included to ensure that the meaning of each issue was interpreted consistently across all respondents. These 31 issues have been discussed previously (see Pervan 1996, 1997). The questionnaire also contained a brief set of questions seeking information on current characteristics of the organisation (ownership, business activity, structure, management style) and of future plans (in market share, staffing, acquisitions, diversification, and IT outsourcing).

\section{THE RESULTS OF THE STUDY}

Valid questionnaires were received from 33 of the 452 organisations. While the response rate of $7.3 \%$ is low, it may be considered reasonable for the group targeted (namely the CEOs of Australia's largest organisations, and hence very busy people). Table 3 below shows that these are indeed large organisations with revenue, assets and profits measured in the billions of dollars. Table 4 shows the location of company headquarters and the sector to which that organisation's primary activity belongs. These tables show that, though the sample is relatively small, a wide range of the organisations targeted (from the 13th and 486th ranked organisations) did respond and the results may be moderately generalisable for large Australian organisations. Nevertheless, the discussion which follows should be read as only 'indicative' because of the response rate. 


\section{Technology Management Issues}

Building a responsive IT infrastructure

Measuring IS effectiveness and productivity

Improving data integrity and quality assurance

Developing and managing electronic data interchange

Planning and integrating multi-vendor open systems technologies

Integrating data processing, office automation, and telecommunications;

Managing data and document storage

Planning and managing communications networks

Implementing and managing collaborative support systems

Establishing effective disaster recovery capabilities

\section{Strategic Management Issues}

Improving is strategic planning

Developing and implementing an information architecture

Aligning the is organisation within the enterprise

Outsourcing selected information services

Determining appropriate is funding levels;

Facilitating and managing business process redesign

Using information systems for competitive advantage

\section{People Management Issues}

Recruiting and developing IS human resources

Facilitating organisational learning

Educating senior management in relation to IT

Increasing understanding of IS role and contribution

Systems development and data management issues

Improving the effectiveness of software development

Selecting and integrating packaged applications software

Making effective use of the data resource

Managing the existing portfolio of legacy applications

Developing and managing distributed systems

Improving information security and control

Planning and managing the applications portfolio

Planning and using case technology

End-user Computing Issues

Facilitating and managing end-user computing

Facilitating/managing executive and decision support systems

Table 2: List of Key Issues and Categories

\begin{tabular}{|c|c|c|c|c|}
\hline Variable & $\begin{array}{c}\text { Mean } \\
(\mathbf{\$ b})\end{array}$ & St. Dev. $\mathbf{( \$ b )}$ & $\begin{array}{c}\text { Min. } \\
(\mathbf{\$ b})\end{array}$ & $\begin{array}{c}\text { Max. } \\
\mathbf{( \$ b )}\end{array}$ \\
\hline Revenue & 0.722 & 1.222 & 0.172 & 6.536 \\
\hline Assets & 0.905 & 1.800 & 0.054 & 9.218 \\
\hline Profit & 0.048 & 0.127 & -0.092 & 0.579 \\
\hline
\end{tabular}

Table 3: Respondent Organisations - Financial Data

\begin{tabular}{|l|c|c|c|c|c|c|c|c|c|}
\hline Hector & Vic & NSW & SA & Qld & WA & Tas & ACT & NT & Total \\
\hline Resources/Mining & 1 & 1 & 1 & 1 & & & & & 4 \\
\hline Retai/Trading & 1 & 1 & & & & & & & $\mathbf{2}$ \\
\hline Services & & 1 & 1 & 2 & 1 & 1 & & & 6 \\
\hline Manufacturing & 9 & 2 & 2 & & 4 & & & & 17 \\
\hline Government & 1 & & & & & & 2 & 1 & 4 \\
\hline Total & $\mathbf{1 2}$ & $\mathbf{5}$ & $\mathbf{4}$ & $\mathbf{3}$ & $\mathbf{5}$ & $\mathbf{1}$ & $\mathbf{2}$ & $\mathbf{1}$ & $\mathbf{3 3}$ \\
\hline
\end{tabular}

Table 4: Respondent Organisations - HQ and Industry Sector 
As Table 4 above indicates, responses were received from all states and territories. The largest sector represented in the sample (and in the target Top 500 population) was manufacturing (51\%), while major government instrumentalities for energy, water, and transport made up the $12 \%$ from the government sector. The two most populous states, New South Wales and Victoria, made up $51 \%$ of the sample, confirming that the majority of company headquarters of large Australian organisations are in Sydney and Melbourne. The representation of industry sectors, states, and company finances (assets, profit, revenue) was similar to the corresponding groups in the CIO study.

Ownership of most of these organisations is Australian (64\%), as is the focus of their business activity (only $18 \%$ international). Organisational structure was mostly flat $(63 \%$ vs $37 \%$ hierarchical), mostly along divisional/functional lines ( $82 \%$ vs $18 \%$ cross-functional), centralisation was evenly split between centralised and decentralised, and management style varied between 'formal procedures and rules' (19\%), 'few rules, greater autonomy' (37\%), and 'co-operative and group-oriented' (44\%). Most were planning expansion of sales/market share $(90 \%)$, more acquisitions ( $80 \%)$, greater diversification of products and services $(61 \%)$ and greater IT outsourcing $(67 \%)$, while reducing staff numbers in the organisation (59\%).

\section{Critical Issues}

As indicated earlier, respondents were asked to rate both how imporant an issue will be for their organisation over the next 3-5 years, and how problematic the issue might be. These were both rated on a 1 to 10 scale where 1 represented a lowest priority issue and 10 represented a highest priority issue. All respondents provided a score for both on all issues. As in the CIO study, how critical an issue was to the organisation's CEO was calculated as the arithmetic mean of the ratings for important and problematic. The ten most critical issues, with their ranking, mean and standard deviation of critical rating, are shown in Table 4 below. A full list showing mean and standard deviation for all 31 issues is provided as Appendix A.

\begin{tabular}{|c|c|c|c|c|}
\hline Rank & ISSUE & $\begin{array}{c}\text { Issue } \\
\text { Category }\end{array}$ & $\begin{array}{c}\text { Mean } \\
\text { Rating }\end{array}$ & $\begin{array}{c}\text { Std. } \\
\text { Dev }\end{array}$ \\
\hline 1 & Making effective use of the data resource & SDDM & 7.16 & 1.78 \\
\hline 2 & Building a responsive IT infrastructure & TM & 6.97 & 1.34 \\
\hline 3 & Facilitating organisational learning & PM & 6.84 & 1.64 \\
\hline 4 & Facilitating and managing business process redesign & SM & 6.83 & 1.70 \\
\hline 5 & Using information systems for competitive advantage & SM & 6.80 & 1.85 \\
\hline 6 & Measuring IS effectiveness and productivity & TM & 6.77 & 1.65 \\
\hline 7 & Developing and implementing an information architecture & SM & 6.75 & 1.40 \\
\hline 8 & Establishing effective disaster recovery capabilities & TM & 6.73 & 1.78 \\
\hline 9 & Improving the effectiveness of software development & SDDM & 6.64 & 1.94 \\
\hline 10 & Facilitating/managing executive and decision support systems & EUC & 6.58 & 1.91 \\
\hline
\end{tabular}

\section{Table 5: The Ten Most Critical Issues}

The relative ranking of issues within the top 10 should not be overly highlighted because their mean ratings range only by 0.58 on a 10 -point scale and the average standard deviation is 1.70 . However, it is interesting to note that each of the five issue categories have one or more issues in this top group. While it might be supposed that CEOs would not be overly concerned with technology management, this is contradicted by the appearance of $I T$ infrastructure, disaster recovery, and IS effectiveness measurement (all technology management issues). However, this should come as no surprise in such a rapidly changing technological environment. It is clear that the provision of a responsive IT infrastructure (ranked \#2) is a fundamental concern for the organisation and that the ability of that infrastructure to respond to disaster situations is an organisation-wide problem in the 1990s. A closer examination of the data revealed that a responsive IT infrastructure was rated significantly higher (in a one-way ANOVA at the $1 \%$ level) by CEOs planning expansion in staffing and greater diversification of products and services in the next 3-5 years. In these organisations the IT infrastructure would depended on to support this increased organisational size and complexity.

Many organisations would not be able to survive more than a few days without their IT facilities (O'Brien 1993) so disaster recovery (ranked \#8) might be expected to be a major issue. Measuring the effectiveness and productivity of the organisation's information systems and technology (ranked \#6) is clearly of major concern to the CEOs given the scale of investment in this infrastructure. Clearly, the CEOs are expecting 'value for money', 
and rightly so. Sensibly, the CEOs recognised that this issue was particularly critical if they were planning increased IT outsourcing (as indicated by a significantly higher critical rating for measuring IS effectiveness among organisations planning more IT outsourcing).

Educational issues also rank highly, with organisational learning ranked 3rd and EIS/DSS (which involves similar motivations and contains a significant user training/education component)) ranked 10th. Organisations (and the people in them) require continuous learning about ways to better utilise the information resource and integrate new technologies into the organisation (Niederman et al. 1991). IT education is therefore critical and can lead to increased productivity and reduced applications backlogs (Brancheau and Brown 1993). Significant increases in innovation and productivity from an organisation's IT investment can be derived from an emphasis on supporting and managing organisational learning in the organisation (Henderson and Lentz 1996). The high ranking of EIS/DSS may be interpreted as a concern by CEOs for their own personal support, but these systems are aimed at supporting managers and decision makers in organisations (Laudon and Laudon 1991) and CEOs would see this as key to the effective operation of the organisation.

Strategic management issues which ranked highly were business process redesign, IS for competitive advantage, and information architecture. Business process redesign (ranked \#4) has been a top issue among CEOs and CIOs for several years (Watson et al. 1997). Many organisations are focusing on a radical redesign of their business processes in order to achieve dramatic improvements in performance and innovative and effective applications of information technology are seen by many as a vehicle for achieving this (Hammer and Champy 1993). Further analysis revealed that BPR was seen to be significantly more critical for organisations planning to concentrate their activities more, perhaps reflecting that some radical redesign of existing processes may be necessary to achieve this concentration effectively. Further, through the innovative use of IT, organisations may find new ways to realise competitive advantage.

A corporate information architecture (ranked \#7) is a high-level map of the information requirements of an organisation (Brancheau and Wetherbe 1987) which is used to identify key information needs and how this information relates to key business processes. Its development is necessary in order to guide the development of these innovative applications and facilitate the integration and sharing of data (Niederman et al. 1991). Further analysis revealed that this issue was significantly more critical for more decentralised organisations, an indicator that this high level information map may be more difficult to develop in more decentralised organisations.

The CEOs also perceive the effective use of the data resource and the effectiveness of software development as critical issues. The data resource in most organisations is becoming larger, more complex, and greater in cost and value. Matheus et al. (1993) claim that the data resource is often poorly recognised, difficult to access, and poorly utilised. Effective information systems can provide users with timely, accurate, and relevant information, but the backlog in the development of these systems remains at unacceptably high levels in many organisations (Laudon and Laudon 1994). This is exacerbated by changing hardware platforms and new software development tools arriving on the market, which the developers have to learn and utilise. The CEOs, understandably, are particularly concerned with maximising the return from their substantial investment in IT and having it available on time, in budget, and with the right form and content.

In summary, the most critical issues were revealed to be a mix of technology management issues, strategic management issues, people management issues, systems development and data management issues, and end-user computing. This reflects a broad range of concerns for the CEO in relation to IT. However, a closer examination of the issues reveals a major concern for organisation-wide issues and optimising the return from their IT investment.

\section{Non-Critical Issues}

\begin{tabular}{|c|c|c|c|c|}
\hline Rank & ISSUE & $\begin{array}{c}\text { Issue } \\
\text { Category }\end{array}$ & $\begin{array}{c}\text { Mean } \\
\text { Rating }\end{array}$ & $\begin{array}{c}\text { Std. } \\
\text { Dev. }\end{array}$ \\
\hline 22 & Managing existing portfolio of legacy applications & SDDM & 6.05 & 2.19 \\
\hline 23 & Developing and managing distributed systems & SDDM & 6.02 & 1.97 \\
\hline 24 & Outsourcing selected information services & SM & 5.92 & 2.02 \\
\hline 25 & Increasing understanding of IS role and contribution & PM & 5.91 & 1.88 \\
\hline 26 & Managing data and document storage & TM & 5.83 & 1.85 \\
\hline 27 & Determining appropriate IS funding levels & SM & 5.75 & 1.87 \\
\hline 28 & Recruiting and developing IS human resources & PM & 5.63 & 1.97 \\
\hline 29 & Multi-vendor open systems technologies & TM & 5.48 & 2.34 \\
\hline 30 & Planning and managing the applications portfolio & SDDM & 5.31 & 1.97 \\
\hline 31 & Planning and using CASE technology & TM & 4.58 & 2.32 \\
\hline
\end{tabular}

Table 6: The Ten Least Critical Issues 
The issues which were rated the ten least critical are shown in Table 6 above. Overall, it may be observed that individual technology management and systems development and data management issues are of little concem to the CEO. Six of the ten least critical issues relate to individual information technologies (\#26 data/document storage, \#29 multi-vendor integration, and \#31 CASE technology) and three relate to specific systems management issues (\#22 legacy applications, \#23 distributed systems, and \#30 applications portfolio). While these individual systems and technologies are part of the overall infrastructure, they may be seen to be the province of the CIO (as is the recruitment/development of their IS human resources, \#28), while it is their overall responsiveness, usefulness and stability which is of greater concern to organisation as a whole. The same argument may hold true for IT outsourcing (\#24) as it may be seen as the CIOs job to determine what is actually provided in-house or outsourced and the CEO is interested only in results. (Not surprisingly, the further analysis revealed that IT outsourcing was seen to be a significantly more critical issue for those organisations planning more IT outsourcing in the next 3-5 years.)

The results in Table 6 also reveal that the CEOs show little concern for understanding IS role and contribution (\#25) and determining appropriate IS funding levels (\#27). These issues may also be seen by the CEO as a job for the CIOs and their area.

\section{Comparison of Australian CEOs and CIOs}

The ranking of the critical issues as perceived by the Australian CIOs in the final round of the 1996/97 study have been added in the final column of Appendix A. The Spearman's rank correlation calculated on the paired (CEO and CIO) rankings was 0.6956 which is significant at the $0.1 \%$ level. This confirms that there is substantial agreement between the views of the CIOs and CEOs on the key IS issues in these large organisations. That there is fairly strong consensus on the key issues is a positive sign and may indicate the fairly advanced stage of IT growth in these large organisations and sound lines of communication between CIOs and CEOs in these organisations. However, there are some distinct differences in CEO and CIO rankings on a few issues and these are summarised in Table 7 below.

\begin{tabular}{|c|c|c|}
\hline CEO Rank & ISSUE & CIO Rank \\
\hline \multicolumn{3}{|c|}{ Issues more critical to the CEO than to the CIO } \\
\hline 4 & Facilitating and managing business process redesign & 18 \\
\hline 6 & Measuring IS effectiveness and productivity & 12 \\
\hline 7 & Developing and implementing an information architecture & 15 \\
\hline 9 & Improving the effectiveness of software development & 22 \\
\hline 12 & Improving data integrity and quality assurance & 19 \\
\hline \multicolumn{3}{|c|}{ Issues more critical to the CIO than to the CEO } \\
\hline 13 & Educating senior management in relation to IT & 3 \\
\hline 15 & Planning and managing communications networks & 5 \\
\hline 19 & Improving IS strategic planning & 6 \\
\hline 25 & Aligning the IS organisation within the enterprise & 10 \\
\hline & Increasing understanding of IS role and contribution & 13 \\
\hline
\end{tabular}

\section{Table 7: Issues Seen Differently by CEOs and CIOs}

The first five issues above are those much more critical to CEOs than to CIOs. All of these issues can be interpreted to have a focus on ensuring that the organisation's IS and IT delivers on its promises. Quality and effectiveness of data and systems are the common themes in these issues. While it is clearly appropriate for the CEOs to be concerned with these issues it is perhaps a little alarming that the CIOs do not show quite the same concern for providing the services whose delivery is their responsibility. IS departments and their managers in these large Australian organisations may need to be more focused on service and on perceiving the non-IS people in the organisation as 'customers' rather than 'users' (Pitt et al. 1995).

The last five issues above are those more critical to the CIOs than to CEOs. It is quite reasonable that communications networks, the key technology underpinning the $\Pi \mathrm{T}$ infrastructure now and in the future, should be ranked higher by CIOs as it is their specific function to ensure that this technology works effectively. It is also reasonable that issues such as IS planning, IS organisational alignment, and increasing understanding of the IS role and contribution should all be ranked higher by the CIOs as they are essentially their responsibility. However, it is interesting (perhaps even amusing) to observe that $\mathrm{CIO}$ see a greater need for the IT education of senior management than do the senior managers themselves! This difference of view about the senior 
management's IT knowledge may reflect the long-held perception by IS professionals that a poorly educated (in relation to IT) senior management is a continuing obstacle to IT growth. Interestingly; the same difference of opinion on senior management IT education occurred in the most recent UK study (Galliers et al. 1994). However, their is inherent danger in this apparent conflict of views on the senior management's need for greater IT education which may need to be addressed with better communication.

In summary, there is a good degree of consensus between Australian CEOs and CIOs on the key IS management issues and, except for the IT education of senior management, any differences are explainable by their roles and so could be considered reasonable.

\section{CONCLUSIONS, LIMITATIONS AND FURTHER RESEARCH}

This paper has presented some results from a study of the key issues facing chief executives in Australia's largest organisations. The most critical issues were a mix of technology management issues (TT infrastructure, measuring IS effectiveness, disaster recovery), strategic management issues (business process redesign, competitive advantage, responsive information architecture), people management issues (organisational learning), systems development and data management issues (effective use of the data resource, effectiveness of software development), and end-user computing (executive and decision support systems). This range of IS management issues are of major concern to CEOs. However, it is quite clear that CEOs are greatly concerned with 'the bottom line' in relation to their IT infrastructure with effectiveness in relation to the data resource, software development, and the measurement of the IS function generally. CEOs want a sound return on their IT investment and it is the role of the IT professionals to ensure that they are effective and can be shown to be so (with appropriate measurement).

Issues perceived by the CEOs as non-critical were mostly related to the management of specific systems and several individual technologies which must be integrated and managed to ensure a responsive IT infrastructure, as well as a number of clearly CIO roles. TT outsourcing was ranked surprisingly low (considering its apparent popularity), but it did rate as a more critical issue for those organisations actually planning to implement IT outsourcing in the next few years. These same organisations considered the measurement of effectiveness of their IS as more critical as this would be a key factor in what functions to outsource and to what extent.

On a positive note, CIOs and CEOs were in broad agreement on the majority of the issues though the CEOs had, as would be expected, a more organisation-wide focus and were clearly more concerned about receiving a good return from their substantial IT investment. On the other hand, for CIOs some of the more critical issues were directly concerned with their specific role in managing the organisation's IS/TT. These differences are as would be expected according to the roles filled by CEOs and CIOs. However, CIOs perceived the senior management's IT education as a more critical issue than the CEOs themselves and this may imply a lack of communication or at least of understanding of each other.

This survey has some limitations associated with the response rate, but the results were interesting and the comparisons between CEOs and CIOs of some value. It is hoped that by providing both target groups with the results of both surveys, they will see where their differences of opinion are, and this may lead to better communication between them so that these differences might diminish over time. Further analysis of both surveys is being undertaken and comparisons are being followed up with recent similar studies in other countries. It is hoped that this and other follow-up studies will serve to assist CEOs, CIOs, and IS researchers identify areas of interest in the management of information systems and information technology. Further, to assess the limitation imposed by the low response rate, a follow-up mailout to non-respondents is planned and non-response bias will be measured.

\section{REFERENCES}

Brancheau, J.C. and Brown, C.V. (1993) "The Management of End-User Computing: Status and Directions", ACM Computing Surveys, 25, 437-481.

Brancheau, J.C., Janz, B.D. and Wetherbe, J.C. (1996) "Key Issues in Information Systems Management: A Shift Toward Technology Infrastructure", MIS Quarterly, 20, 2, 225-242.

Brancheau, J.C. and Wetherbe, J.C. (1987) "Key Issues in Information Systems Management", MIS Quarterly, $11,23-45$.

Caudle, S.L., Gorr, W.P. and Newcomer, K.E. (1991) "Key Information Systems Management Issues for the Public Sector", MIS Quarterly, 15, 170-188.

Clark, T.D., Jr. (1992) "Corporate Systems Management: An Overview and Research Perspective", Communications of the ACM, 35, 61-75. 
Davis, J.G., Menon, R., Munday, S.R., Thomson, B.G. and Young, L.W. (1995) "Key Issues in Information Systems Management: A New Zealand Perspective", Proceedings of the PRIISM'95 International Conference, Maui, Hawaii, January 2-3, 187-195.

Galliers, R.D., Merali, Y. and Spearing, L. (1994) "Coping with Information Technology? How British Executives Perceive the Key Information Systems Management Issues in the Mid-1990s", Journal of Information Technology, 9, 223-238.

Hammer, M. and Champy, J. (1993) Re-engineering the Corporation: A Manifesto for Business Revolution. Harper Collins Publishers, Inc., New York.

Henderson, J.C. and Lentz, C.M.A. (1996) "Learning, Working, and Innovation: A Case Study in the Insurance Industry", Journal of Management Information Systems, 12, 43-64.

Jacques, B. (1995) "Top 500: Overview of the Year", The Bulletin, December 5, 4-50.

Laudon, K.C. and Laudon, J.P. (1991) Management Information Systems: Organisation and Technology. Macmillan, New York.

Matheus, C.J., Chan, P.K. and Piatetsky-Shapiro, G. (1993) "Systems for Knowledge Discovery in Databases", IEEE Transactions on Knowledge and Data Engineering, 5, 6, December.

Moynihan, T. (1990) "What Chief Executives and Senior Managers Want from their IT Departments", MIS Quarterly, 14, 15-26.

Niederman, F., Brancheau, J. and Wetherbe (1991) "Information Systems Management Issues for the 1990s", MIS Quarterly, 15, 474-500.

O'Brien, J.A. (1993) Management Information Systems: A Managerial End User Perspective. Irwin, USA.

Pervan, G.P. (1994) "Information Systems Management: An Australian View of the Key Issues", Australian Journal of Information Systems, 1, 32-44.

Pervan, G.P. (1996) "Results from a Study of Key Issues in Australasian IS Management -1996", Proceedings of the 7th Australasian Conference on Information Systems, University of Tasmania, December, 509 520 .

Pervan, G.P. (1997) "Information Systems Management: An Australasian View of the Key Issues - 1996", Australian Journal of Information Systems, 5, 1, 55-68.

Pith, L.F., Watson, R.T. and Kavan, C.B. (1995) "Service Quality: A Measure of Information Systems Effectiveness", MIS Quarterly, 19, 173-187.

Watson, R.T., Kelly, G.G., Galliers, R.D. and Brancheau, J.C. (1997) "Key Issues in Information Systems Management: An International Perspective". Journal of Management Information Systems, (to appear). 
Appendix A: CEO's Critical Scores for all Key Issues

\begin{tabular}{|c|c|c|c|c|c|}
\hline Rank & ISSUE & $\begin{array}{c}\text { Issue } \\
\text { Category }\end{array}$ & $\begin{array}{l}\text { Mean } \\
\text { Rating }\end{array}$ & $\begin{array}{l}\text { Std. } \\
\text { Dev. }\end{array}$ & $\begin{array}{c}\text { CIO } \\
\text { Rank }\end{array}$ \\
\hline 1 & Making effective use of the data resource & SDDM & 7.16 & 1.78 & 2 \\
\hline 2 & Building a responsive IT infrastructure & TM & 6.97 & 1.34 & 1 \\
\hline 3 & Facilitating organisational learning & PM & 6.84 & 1.64 & 7 \\
\hline 4 & Facilitating and managing business process redesign & SM & 6.83 & 1.70 & 18 \\
\hline 5 & Using information systems for competitive advantage & SM & 6.80 & 1.85 & 4 \\
\hline 6 & Measuring IS effectiveness and productivity & $\mathrm{TM}$ & 6.77 & 1.65 & 12 \\
\hline 7 & Developing and implementing an information architecture & SM & 6.75 & 1.40 & 15 \\
\hline 8 & Establishing effective disaster recovery capabilities & TM & 6.73 & 1.78 & 8 \\
\hline 9 & Improving the effectiveness of software development & SDDM & 6.64 & 1.94 & 22 \\
\hline 10 & Facilitating/managing executive and decision support systems & EUC & 6.58 & 1.91 & 14 \\
\hline 11 & Improving information security and control & SDDM & 6.53 & 1.75 & 11 \\
\hline 12 & Improving data integrity and quality assurance & TM & 6.50 & 1.63 & 19 \\
\hline 13 & Educating senior management in relation to $\mathrm{IT}$ & PM & 6.48 & 1.91 & 3 \\
\hline 14 & Facilitating and managing end user computing & EUC & 6.47 & 1.94 & 9 \\
\hline 15 & Planning and managing communications networks & TM & 6.33 & 1.72 & 5 \\
\hline 16 & Improving IS strategic planning & SM & 6.22 & 1.71 & 6 \\
\hline 17 & Selecting and integrating packaged applications software & SDDM & $\overline{6.19}$ & 1.98 & 16 \\
\hline 18 & Developing and managing electronic data interchange & TM & 6.19 & 1.90 & 28 \\
\hline 19 & Aligning the IS organisation within the enterprise & SM & 6.19 & 1.92 & 10 \\
\hline 20 & $\begin{array}{l}\text { Integrating data processing, office automation, } \\
\text { telecommunications }\end{array}$ & TM & 6.17 & 1.54 & 20 \\
\hline 21 & Implementing and managing collaborative systems & TM & 6.05 & 2.10 & 30 \\
\hline 22 & Managing existing portfolio of legacy applications & SDDM & 6.05 & 2.19 & 27 \\
\hline 23 & Developing and managing distributed systems & SDDM & 6.02 & 1.97 & 21 \\
\hline 24 & Outsourcing selected information services & SM & 5.92 & 2.02 & 29 \\
\hline 25 & Increasing understanding of IS role and contribution & PM & 5.91 & 1.88 & 13 \\
\hline 26 & Managing data and document storage & TM & 5.83 & 1.85 & 24 \\
\hline 27 & Determining appropriate IS funding levels & SM & 5.75 & 1.87 & 23 \\
\hline 28 & Recruiting and developing IS human resources & PM & 5.63 & 1.97 & 17 \\
\hline 29 & Multi-vendor open systems technologies & TM & 5.48 & 2.34 & 26 \\
\hline 30 & Planning and managing the applications portfolio & SDDM & 5.31 & 1.97 & 25 \\
\hline 31 & Planning and using CASE technology & TM & 4.58 & 2.32 & 31 \\
\hline
\end{tabular}

${ }^{1}$ Source: Pervan (1997) 